\title{
Comparison of Sleep Quality, Waist Circumference and Body Mass Index Among Shift and Non-shift Workers
}

\author{
Vardiyalı ve Vardiyasız Çalıșanlarda Uyku Kalitesi, Bel Çevresi ve Beden Kitle \\ Indeksinin Karșılaștırılması
}

\author{
(1) Hazal Çatırtan, ๑ Binnur Okan Bakır* \\ Acıbadem Altunizade Hospital, Clinic of Nutrition and Dietetics, Istanbul, Turkey \\ *Yeditepe University, Faculty of Health Sciences, Department of Nutrition and Dietetics, Istanbul, Turkey
}

\begin{abstract}
Objective: Sleep is a reversible condition in which the creature's response threshold increases to external stimuli. A good night's sleep is one of the most important components of health and quality of life and short or long sleep duration is associated with obesity. This study aimed to compare body mass index (BMI) and waist circumference with sleep quality and shift status in shift or non-shift workers of a private hospital in Istanbul.

Materials and Methods: A questionnaire was applied to 202 participants, Pittsburgh Sleep Quality index scores were evaluated and a sleep diary was filled. Participants' waist circumference, height and weight were measured, BMI values were calculated.

Results: The results were evaluated according to shift status and sleep quality, and the sleep quality was found to be significantly poor for shift worker female participants. According to shift status, non-shift workers' $\mathrm{BMI}$ and waist circumference were determined significantly higher than shift workers' regardless to gender. The mean BMI values decreased as the shift frequency increased in female and male participants. The participants with poor sleep quality and non-shift were found to have higher BMI values.

Conclusion: The current literature results are controversial which investigates the relationship between sleep quality, waist circumference and body mass index among the shift and non-shift workers, and these results require to be clarified. On the basis of these results, both individual and employer based precautions should be well organised.
\end{abstract}

Keywords: Nutrition, shift work, sleep quality, obesity
Öz

Amaç: Uyku, canlının dış uyaranlara tepki eşiğinin arttığı tersine çevrilebilir bir durumdur. lyi bir gece uykusu, sağlığın ve yaşam kalitesinin en önemli bileşenlerinden biridir ve kısa veya uzun uyku süresi obezite ile ilişkilidir. Bu çalışmada, İstanbul'da özel bir hastanenin vardiyalı veya vardiyasız çalışanlarında beden kitle indeksi (BKI) ve bel çevresi ile uyku kalitesi ve vardiya durumunun karşılaştırılması amaçlanmıştır.

Gereç ve Yöntem: İki yüz iki katılımcıya anket uygulanmış ve Pittsburgh Uyku Kalitesi indeksi puanları değerlendirilmiş ve uyku günlüğü doldurmuştur. Katılımcıların bel çevresi, boy ve kiloları ölçülmüş, BKI değerleri hesaplanmıştır.

Bulgular: Sonuçlar vardiya durumuna ve uyku kalitesine göre değerlendirilmiş, vardiyalı çalışan kadın katıımcıların uyku kalitesi anlamlı olarak kötü bulunmuştur. Vardiya durumuna göre, vardiyalı olmayan çalışanların BKI ve bel çevresi, vardiyalı çalışanlardan cinsiyete bakılmaksızın, anlamlı derecede yüksek olarak saptanmıştır. Kadın ve erkek katılımcılarda vardiya sıklığı arttıkça ortalama BKI değerlerinin azaldığı, uyku kalitesi kötü olan ve vardiyalı olmayan çalışanların daha yüksek BKi değerlerine sahip olduğu görülmüştür.

Sonuç: Vardiyalı ve vardiyalı olmayan çalışanlar arasında uyku kalitesi, bel çevresi ve BKI arasındaki ilişkiyi inceleyen güncel literatürde sonuçlar tartışmalıdır ve netleştirilmesine ihtiyaç vardır. Bu sonuçlara dayanarak hem bireysel hem de işveren bazlı önlemler iyi organize edilmelidir.

Anahtar Kelimeler: Beslenme, vardiyalı çalışma, uyku kalitesi, obezite

\section{Introduction}

Sleep is a reversible condition in which the creature's response threshold increases to external stimuli (1). It is located at the bottom of the pyramid diagram called as "Maslow's Hierarchy of Needs" and a good night's sleep is considered to be one of the most important components of health and quality of life at all ages (2).
Systematic studies showed that short or long sleep duration are associated with hypertension, cardiovascular disease, stroke, type 2 diabetes mellitus and obesity (3-8). The fact that they both have negative health consequences leads to an increase in the need for regular and qualified sleep.

Although the effects of sleep on nutrition were studied in individuals with psychological problems in the 1970s,

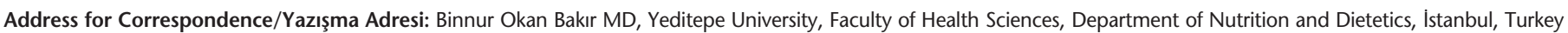
E-mail: binnur.bakir@yeditepe.edu.tr ORCID-ID: orcid.org/0000-0002-0448-4300

Received/Geliş Tarihi: 11.04.2018 Accepted/Kabul Tarihi: 12.08.2018

${ }^{\circ}$ Copyright 2018 by Turkish Sleep Medicine Society / Journal of Turkish Sleep Medicine published by Galenos Publishing House. 
health-related effects of chronic sleep deprivation were first investigated by Spiegel et al. (9). and its relationship with nutrition started to take shape (10).

According to the International Classification of Sleep Disorders, there are 8 types of sleep disorders and nutrition is affected mostly by shift work sleep disorder (11). Disruption of sleep patterns, shortening of sleep duration, etc. in shift work affect circadian rhythms of individuals, disrupt hormonal and metabolic balance in the body, cause impairment of hypertension, insulin resistance and lipid profile. While irregular sleep schedules makes appetite control harder, it also triggers unhealthy behaviors such as increased food consumption at night $(12,13)$. In addition, it has been shown that the weight gain, body mass index (BMI) value and waist circumference rates of the night workers are higher $(14,15)$.

Healthcare workers are also the most common examples for shift work system. This study has been carried out in order to compare waist circumference, BMI and food choices of individuals who works in a private hospital according to their sleep quality and shift status.

\section{Materials and Methods}

This research was carried out in İstanbul between December 2016 and February 2017 with of 202 individuals who work at Anadolu Medical Center Hospital. For this study, the ethics committee approval dated 24/11/2016 from the Ethics Committee of Anadolu Medical Center Hospital was taken (ASM-EK-16/40). A written informed consent form obtained from the participants as to their voluntary participation in the work. People who works at Anadolu Medical Center Hospital, voluntarily participated and individuals aged 18-65 years were included. They were separated as day worker (non-shift worker) and day-night worker (shift worker). The individuals who are working in day-night shift for more than 3 months were chosen as shift workers. Pregnant women and individuals with chronic diseases needed nutritional intervention were excluded. Two hundred twenty six of 250 individuals volunteered. Nineteen of 226 individuals had chronic diseases and 5 of 226 individuals were pregnant so they were excluded. A total of 202 individuals were participated in the study, 111 of them were shift workers and 91 of them were non-shift workers.

A questionnaire consisting of a total of 24 questions about personal and demographic information, information about eating habits and patterns, information about exercise, and information about relationship between emotional status, sleep and nutrition were assessed in the questionnaire. The questionnaire form was filled by the researcher with face to face interviews.

Participants' body weights were measured using Inbody 230 brand bioelectrical impedance analyzer. During the measurement, the feet were placed naked and dry, corresponding to the electrodes on the device. It has been paid attention that there was no extra weight on the participants in the measurement like belt, wallet etc. Height of participants was measured using the Seca brand electronic length meter. Care has been taken to ensure that the patient's feet are sideby-side and that the head is in the plane of Frankfurt (90 degrees between head and neck) while measuring height. BMI of participants were calculated by using weight and height of participants with the formula of BMI: [weight $(\mathrm{kg}) /$ height $(\mathrm{m})^{2}$. The results were assessed according to World Health Organization's BMI classification (16).

For waist circumference measurement, the individuals stood still, gathered their feet and opened their arms parallel to the ground. The region between the lowest rib bone and iliac crest was found and then the waist circumference passing through the center was measured with a tape. For every individual the measurement was made naked.

Sleep quality was determined with Pittsburgh Sleep Quality index (PSQI) which is a self-reported scale assessing sleep quality and impairment over a period of one month. There are 24 questions and 19 of them are self-reported. Other 5 questions are answered by the roommate or husband/wife and do not participate in scoring (17). PSQI had been demonstrated by Buysse et al. (18) with the sufficient internal consistency (Cronbach's alpha $=0.80$ ), test-retest reliability and validity in 1989. The validity and reliability study of PSQI in Turkey were assessed by Ağargün et al. (19) in 1996. Additionally a sleep diary was used to record the sleep-wake pattern in a daily basis. It aimed to measure the pattern and quality of individuals' sleep, and factors that may affect their sleep (20). A sleep diary held for 7 days was used to support other findings and be informed about participants' sleep patterns, habits and stress levels.

\section{Statistical Analysis}

For the evaluation of findings, SPSS version 22.0 was used. Additionally, chi-square analysis, independent group comparisons (independent t-test), ANOVA-Wilks' lambda tests were used.

Descriptive statistics such as frequency, arithmetic mean, standard deviation, minimum, maximum, frequency, percentage were used in analyzing the data. Our data set was based on parametric statistical analysis. Independent t-test was used in the comparison of the two groups with respect to the chisquare relationship analysis, and ANOVA-Wilks' lambda result was used in the comparison of the two groups. Significance was accepted as $p<0.05$ and $p<0.01$ as very significant.

\section{Results}

Two hundred two healthy individuals were participated in our study. $77.7 \%$ of them were women $(n=157)$ and $22.3 \%$ were men $(n=45)$. Average age of participants was $34.4 \pm 7.87$ years. Shift worker women's mean BMI was $23.01 \pm 4.02 \mathrm{~kg} / \mathrm{m}^{2}$, mean weight was $61.22 \pm 11.55 \mathrm{~kg}$ and mean waist circumference was $76.76 \pm 9.40 \mathrm{~cm}$. Non-shift worker women's mean BMI was $23.57 \pm 4.92 \mathrm{~kg} / \mathrm{m}^{2}$, mean weight was $61.93 \pm 13.28 \mathrm{~kg}$ and mean waist circumference was $79.85 \pm 11.92 \mathrm{~cm}$.

Shift worker men's mean BMl was $25.26 \pm 3.12 \mathrm{~kg} / \mathrm{m}^{2}$, mean weight was $77.63 \pm 12.68 \mathrm{~kg}$ and mean waist circumference was $89.29 \pm 8.34 \mathrm{~cm}$. Non-shift worker men's mean BMI was $27.2 \pm 4.55 \mathrm{~kg} / \mathrm{m}^{2}$, mean weight was $85.57 \pm 16.67 \mathrm{~kg}$ and mean waist circumference was $96.15 \pm 12.64 \mathrm{~cm}$.

As evaluated according to "Pillai's trace" and "Wilks' lambda" multivariate tests, sex and shift factors $p$ values were found significant $(p<0.05)$. Sex and shift status have a statistically significant effect on dependent variables separately. It means 
that men's BMI was significantly higher than women's. According to shift status; non-shift workers' BMI, weight and waist circumference were significantly higher than shift workers' $(p<0.05)$. Shift work and sex interaction had not been found effective on dependent variables when examined together $(p=0.233, p>0.05)$. When assessing differences between and within groups, there was no statistical difference found within groups in terms of BMI, weight and waist circumference values on sex and shift levels $(p=0.355, p=0.106, p=0.301, p>0.05)$. This means that the BMI, weight and waist circumference values were not statistically different according to shift status and sex together.

\section{Discussion}

It has been revealed that short sleepers (a duration less than 6 hours) were likely to have a point estimate of an absolute increase of $37 \%$ for diabetes mellitus, $17 \%$ for hypertension, $16 \%$ for cardiovascular disease, $26 \%$ for coronary heart disease and $38 \%$ for obesity (7). A review which includes cohorts and cross-sectional studies, it was found that the published literature supported the presence of an association between sleep duration and weight gain unless there were some confounding factors and results (21). Additionally in a review conducted in 2010, it was shown that being overweight and obese was more prevalent in shift workers than day workers, also shift work was associated with BMI independent of age or time in shift work and a longer exposure predicts a higher BMI (14). In a study which was conducted to see the negative effects of night work load, sex was found positively and significantly related to BMI and night shift worker females had lower BMI values than males (22). In another study which was hold in a private hospital with outpatients, a statistically significant difference between the BMI group distributions according to sex was found. While the frequency of women being underweight and normal was significantly higher than men, the frequency of men being overweight and obese was significantly higher than women (17). Unlike the results of this study and other studies, in a study which evaluates physical activity, sleep quality, metabolic activity and stress levels in health care workers, BMI and waist to hip ratio (WHR) did not show significant differences within the groups and between subgroups. The median BMI and the median WHR in all subpopulation were within the range of healthy individuals, WHR result resembles this study's results. For BMI, a tendency towards overweight was found for all subgroups, whereas the non-shift worker subgroup had the highest median BMI of all subgroups similarly with our results (23). As in this study, it was found that working in the night shift leads to a greater increase in BMI compared to working during the day. But the mean BMI of night workers was $25.5 \mathrm{~kg} / \mathrm{m}^{2}$ and day workers was $25.0 \mathrm{~kg} / \mathrm{m}^{2}$, being the opposite of this results, there were no statistically significant difference found (24). Similarly, a study which was conducted in Korea also found that non-shift workers had a higher prevalence of being overweight and obese than shift workers (25). In a study with pediatric nurses with shifts, there was no statistically significant difference of elevated BMI (>30) found between night shift and day shift respondents unlike this study (26).
When the values of $\mathrm{BMI}$ and waist circumference according to shift frequency in women were examined, it is observed that the mean BMI and waist circumference values showed different tendencies according to shift frequency. Female participants staying night shift once a month and 8-10 days in a month have higher BMI values than others. Female participants staying night shift once a month and 8-10 and 15 days in a month have higher waist circumferences than others. When the values of BMI and waist circumference according to shift frequency in men were examined; it has been observed that the mean BMI and waist circumference values decrease as the shift frequency increases. Male participants staying night shift once and twice a month have higher BMI values than others. Male participants staying night shift once and twice a month have higher waist circumferences than others. According to a study which was conducted in Korea, the overall prevalence of overweight/ obesity (18.6\%) and obesity (7.4\%) increased significantly as shift work duration increased. The participants with the longest duration of shift work were found 1.63 times more likely to be overweight or obese than those with the shortest duration (25). In another study evaluating the relationship between the years of exposure to night work and BMI among registered nurses, the years of exposure to night work was found associated between BMI. When the exposure time increases, the BMI increases. The effect of night work was greater among women than men (27). In a study with male shift-workers, similar results were found with this study. Results suggested that risk of obesity in shift workers was not related to length of exposure to shift work as years (28). In a cross-sectional study evaluating negative effects of night shift, number of nights worked in the last year was statistically significant and positively related to increased BMI values (22). A study which evaluated the shift frequency as night numbers like this study, the positive and statistically significant associations for cumulative night shift work exposure expressed as the total number of night shifts (or of night shift hours) and $\mathrm{BMI}$ and waist circumference. Increased shift-work exposure and increased night shift work were found consistently associated with obesity in women reporting eight or more night shifts per month. A higher frequency of night shifts was also found significantly associated with abdominal obesity (29).

Sleep quality of participants was evaluated by PSQI. When PSQI is 5 or less than 5, the sleep quality of participant considered to be good. But when PSQI is more than 5, the sleep quality of participant is accepted as poor (18). The sleep quality of participants in the study varied by $\operatorname{sex}(p=0.015 ; p<0.05) .70 \%$ $(n=51)$ of the participants with good sleep quality (PSQI $\leq 5)$ were female and $30 \%$ were male $(n=22) .86 \%$ of the participants with poor sleep quality (PSQI $>5)$ were female $(n=106)$ and $14 \%$ were male $(n=23)$. As a result, the sleep quality of women participants found different and better than men's. When the shift status was evaluated within the groups; there was a significant relationship between sleep quality and shift status in women $(p=0.009, p<0.05)$. Sleep quality was good (PSQI $\leq 5)$ in $43 \%$ of shift workers and $57 \%$ of non-shift workers. In addition, $65 \%$ of those with poor sleep quality (PSQI $>5$ ) were found to be shift workers and $35 \%$ non-shift workers. So, it can be said that non-shift workers has significantly better sleep quality. Half of the shift worker male participants had good sleep quality 
and half of them had poor sleep quality. Also, approximately half of the non-shift worker male participants had good sleep quality and half of them had poor sleep quality. As a result, there was no relationship found between sleep quality and the shift status of male participants $(p=0.936, p>0.05)$. In a study which investigates the effects of shift working, PSQI showed no significant differences in the group- and subgroup-analyses. Individuals on a shift-work schedule more often reported an impaired sleep quality as in this study (23). Another study which explored the relationship between shift work, quality of sleep, and BMI of nurses, unlike this results, there was no significant difference found in global sleep quality score between the shift groups. There was no sex difference in global sleep quality score (26). In a study without shift worker group, the frequency of poor sleep quality within women was found to be significantly higher than men as oppose to this study's results (17).

BMI and waist circumference were evaluated based on sleep quality. For male participants with good sleep quality, mean BMI of shift workers was $25.26 \pm 3.28 \mathrm{~kg} / \mathrm{m}^{2}$ and mean waist circumference was $95.25 \pm 9.27 \mathrm{~cm}$, while mean BMI of non-shift workers was $27.03 \pm 3.68 \mathrm{~kg} / \mathrm{m}^{2}$ and mean waist circumference was $89.56 \pm 8.22 \mathrm{~cm}$. For male participants with poor sleep quality, mean BMI of shift workers was $25.27 \pm 3.14 \mathrm{~kg} / \mathrm{m}^{2}$ and mean waist circumference was $96.93 \pm 15.27 \mathrm{~cm}$, while mean BMI of non-shift workers was $27.35 \pm 5.32 \mathrm{~kg} / \mathrm{m}^{2}$ and mean waist circumference was $89.05 \pm 8.88 \mathrm{~cm}$. As a result, it was found that mean waist circumference tend to be higher for shift worker participants and especially for ones with poor sleep quality. BMI tend to be higher for non-shift worker participants, especially for ones with poor sleep quality. But there was no significant difference found in BMI and waist circumference according to men's shift status and sleep qualities (non-shift worker: $\mathrm{p}=0.862 ; \mathrm{p}=0.743 ; \mathrm{p}>0.05$; shift worker: $\mathrm{p}=0.992$; $\mathrm{p}=0.899 ; \mathrm{p}>0.05)$. For female participants with good sleep quality, mean BMI of shift workers was $22.9 \pm 3.58 \mathrm{~kg} / \mathrm{m}^{2}$ and mean waist circumference was $77.2 \pm 9.86 \mathrm{~cm}$, while mean BMI of non-shift workers was $23.14 \pm 3.05 \mathrm{~kg} / \mathrm{m}^{2}$ and mean waist circumference was $78.91 \pm 9.99 \mathrm{~cm}$. For female participants with poor sleep quality, mean BMI of shift workers was 23.05 \pm 4.18 $\mathrm{kg} / \mathrm{m}^{2}$ and mean waist circumference was $76.62 \pm 9.32 \mathrm{~cm}$, while mean BMI of non-shift workers was $23.91 \pm 6.02 \mathrm{~kg} / \mathrm{m}^{2}$ and mean waist circumference was $80.58 \pm 13.33 \mathrm{~cm}$. As a result, it was found that mean waist circumference tend to be higher for nonshift worker participants and especially for ones with poor sleep quality. BMI tend to be higher for non-shift worker participants, especially for ones with poor sleep quality. But there was no significant difference found in BMI and waist circumference according to women's shift status and sleep qualities (nonshift worker: $p=0.507, p=0.577, p>0.05$; shift worker: $p=0.879$, $p=0.802, p>0.05$ ). It seemed that poor sleep quality affected the BMI values and waist circumference negatively even if there was not a significant relationship. In a study which explored the relationship between shift work, quality of sleep, and BMI of nurses, BMI was found to increase as sleep quality decreased with a 3.77 difference in mean BMI between respondents reporting a very good quality of sleep compared to those reporting a very bad quality of sleep (26). In a study with community-dwelling older Spanish women, the group with sleep disorders showed significantly greater values of BMI and waist circumference than those with good sleep quality. There were low, but significant correlations between the disordered sleep score and body composition parameters such as body weight, BMI and waist circumference as in this study (30). In another study which examined the association between sleep quality and different measures of obesity in a population-based sample of adults, in terms of anthropometry, the two groups (poor and good sleep quality) did not differ in BMI and waist circumference (31). In a study with students, it was found that who had poor sleep quality also had lower mean BMI, upper middle arm circumference, triceps skin fold thickness, waist circumference and hip circumference (15). In a study which evaluated the effects of sleep quality on anthropometric measurements, there was no significant difference found between the BMI values of men and women (17).

There was a significant relationship between sleep quality and physical activity status of shift worker women $(p=0.014$, $\mathrm{p}<0.05) .48 \%$ of physically active shift worker women had good sleep quality and $52 \%$ had poor sleep quality. Those who did not have physical activity stated that $17 \%$ of them had good sleep quality and $83 \%$ had poor sleep quality. Shift worker women participants had significantly better sleep quality. There was no relationship found between sleep quality and physical activity status of women workers without shift $(p=0.861, p>0.05)$, but the number of non-shift worker women with poor sleep quality was higher for group that not physically active. There was no significant relationship found between sleep quality and physical activity status of men workers with shift $(p=0.510$, $p>0.05$ ). There was no significant relationship found between sleep quality and physical activity status of men workers without shift $(p=0.265, p>0.05)$. In a study which had been carried out with night shift worker women, $31 \%$ of women were found as physically active (32). In a study with shift-working healthcare personnel, overall average activity in metabolic equivalents of task was not significantly different between the shift- and non- shift working group as in this study. There was a tendency towards less physical activity in the non-shift working nursing staff compared to employees from the non-shift working office staff. Shift-working individuals were significantly more active than non-shift workers like in this study. Employees on shift rotation walked relatively more than individuals on non-shift work (23). In a Brazilian study with shift workers, regarding the association between work shift and physical activity, overall, night shift workers had higher prevalence of physical activity compared to the day shift workers. Increased physical activity was found significantly associated with work shift particularly among females (33) but in a cross-sectional study, males were found to be exercising significantly more than females (22). As oppose to this study's results, a study which was conducted in Korea found that current shift workers were less likely to exercise regularly than non-shift workers (25). A cross-sectional study which was conducted in Italy mentioned that rotating shift workers significantly more active during leisure-time (34) but a study with Canadian nurses mentioned that nurses working a regular daytime schedule have greater utilisation of fitness facilities (35). 


\section{Conclusion}

Shift work affects sleep quality which in turn has effects on BMI and waist circumference in different ways. According to shift status; non-shiftworkers' BMI and waist circumference were significantly higher than shiftworkers' and sex did not affect the relationship in this study. In women, it was observed that the mean BMI values decreased and the waist circumference values increased as the shift frequency increased. In men, it was observed that the mean BMI and waist circumference values decreased as the shift frequency increased. Being physically active may change the effects of shift work and sleep quality from negative to positive. Shift workers found more physically active than others in this study and this may explain the results of low BMI, weight and waist circumference for shift workers. Sleep quality was also found to be significantly poor, especially for shift worker women. The participants who were shift workers with poor sleep quality had higher BMI values. Current literature has conroversial results and the relationship between sleep quality, waist circumference and BMI among shift and non-shift workers still requires to be clarified and if so, both individual and employer based precautions should be well organised.

\section{Ethics}

Ethics Committee Approval: Ethics Committee of Anadolu Medical Center Hospital (date: 24/11/2016 no: ASM-EK-16/40). Informed Consent: A written informed consent form obtained from the participants.

Peer-review: Internally peer-reviewed.

\section{Authorship Contributions}

Surgical and Medical Practices: H.Ç., Concept: H.Ç., B.O.B., Design: H.Ç., B.O.B., Data Collection or Processing: H.Ç., Analysis or Interpretation: H.Ç., Literature Search: H.Ç., Writing: H.Ç.

Conflict of Interest: No conflict of interest was declared by the authors.

Financial Disclosure: The authors declared that this study received no financial support.

\section{References}

1. Jones $\mathrm{BE}$, Kryger ME, Roth T, Dement WC. Principles and practice of sleep Medicine. Philadelphia, Elsevier, 2005.

2. Gunaydin N. The Quality of Sleep and Effects on General Mental Health of Nurses Who Works in a State Hospital. J Psychiatr Nurs 2014;5:33-40.

3. Guo X, Zheng L, Wang J, Zhang X, Zhang X, Li J, Sun Y. Epidemiological evidence for the link between sleep duration and high blood pressure: a systematic review and meta-analysis. Sleep Med 2013;14:324-32.

4. Wang Y, Mei H, Jiang YR, Sun WQ, Song YJ, Liu SJ, Jiang F. Relationship between Duration of Sleep and Hypertension in Adults: A MetaAnalysis. J Clin Sleep Med 2015;11:1047-56.

5. Cappuccio FP, Cooper D, D'Elia L, Strazzullo P, Miller MA. Sleep duration predicts cardiovascular outcomes: a systematic review and meta-analysis of prospective studies. Eur Hear J 2011;32:1484-92.

6. Leng Y, Cappuccio FP, Wainwright NW, Surtees PG, Luben R, Brayne C, Khaw KT. Sleep duration and risk of fatal and nonfatal stroke: a prospective study and meta-analysis. Neurology 2015;84:1072-9.
7. Itani O, like M, Watanabe N, Kaneita Y. Short sleep duration and health outcomes: a systematic review, meta-analysis, and metaregression. Sleep Med 2017;32:246-56.

8. Devine JK, Wolf JM. Integrating nap and night-time sleep into sleep patterns reveals differential links to health-relevant outcomes. J Sleep Res 2016;25:225-33.

9. Spiegel K, Leproult R, Van Cauter E. Impact of sleep debt on metabolic and endocrine function. Lancet 1999;354:1435-9.

10. Crisp AH, Stonehill E, Fenton GW. An aspect of the biological basis of the mind-body apparatus: the relationship between sleep, nutritional state and mood in disorders of weight. Psychother Psychosom 1970;18:161-75.

11. American Academy of Sleep Medicine. International classification of sleep disorders. Diagnostic and coding manual. 2nd ed. Westchester, Illinois: American Academy of Sleep Medicine, 2005.

12. Suwazono $Y$, Dochi M, Sakata K, Okubo Y, Oishi M, Tanaka K, Kobayashi E, Kido T, Nogawa K. A longitudinal study on the effect of shift work on weight gain in male Japanese workers. Obesity (Silver Spring) 2008; 16:1887-93.

13. Lowden A, Moreno C, Holmbäck U, Lennernäs M, Tucker P. Eating and shift work - effects on habits, metabolism and performance. Scand J Work Environ Health 2010;36:150-62.

14. Antunes LC, Levandovski R, Dantas G, Caumo W, Hidalgo MP. Obesity and shift work: chronobiological aspects. Nutr Res Rev 2010;23:155-68.

15. Türközü $D$, Aksoydan $E$. Uyku süresi ve kalitesinin beslenme ve vücut bileşimine etkisi. Sted 2015;24:10-7.

16. World Health Organization. Body mass index - BMI 2017.

17. Öçal Ö. Acıbadem Maslak Hastanesi beslenme ve diyet polikliniğine başvuran yetişkin bireylerde besin tüketiminin Pittsburgh Uyku Kalitesi Ölçeği ile ilişkisi. Başkent Üniversitesi, 2015.

18. Buysse DJ, Reynolds CF, Monk TH, Berman SR, Kupfer DJ. The Pittsburgh Sleep Quality Index: a new instrument for psychiatric practice and research. Psychiatry Res 1989;28:193-213.

19. Ağargün M, Kara H, Anlar Ö. Pittsburgh Uyku Kalitesi İndeksi'nin geçerliliği ve güvenirliliği. Türk Psikiyatr Derg 1996;7:107-15.

20. The Sleep Council. Sleep Diary. Sleep (Rochester).

21. Patel SR, Hu FB. Sh.ort sleep duration and weight gain: a systematic review. Obesity (Silver Spring) 2008;16:643-53.

22. Buchvold HV, Pallesen S, Øyane NM, Bjorvatn B. Associations between night work and BMI, alcohol, smoking, caffeine and exercise a crosssectional study. BMC Public Health 2015;15:1112.

23. Roskoden FC, Krüger J, Vogt LJ, Gärtner S, Hannich HJ, Steveling A, Lerch MM, Aghdassi AA. Physical Activity, Energy Expenditure, Nutritional Habits, Quality of Sleep and Stress Levels in Shift-Working Health Care Personnel. PLoS One 2017;12:e0169983.

24. Marquezea EC, Lemosa LC, Soaresa N, Lorenzi-Filhob G, Morenoa CR. Weight gain in relation to night work among nurses. Work 2012;41(Suppl 1):2043-8.

25. Kim MJ, Son KH, Park HY, Choi DJ, Yoon CH, Lee HY, Cho EY, Cho MC. Association between shift work and obesity among female nurses: Korean Nurses' Survey. BMC Public Health 2013;13:1204.

26. Huth IJ, Eliades A, Handwork C, Englehart JL, Messenger J. Shift worked, quality of sleep, and elevated body mass index in pediatric nurses. J Pediatr Nurs 2013;28:e64-73.

27. Griep RH, Bastos LS, Fonseca Mde J, Silva-Costa A, Portela LF, Toivanen $S$, Rotenberg L. Years worked at night and body mass index among registered nurses from eighteen public hospitals in Rio de Janeiro, Brazil. BMC Health Serv Res 2014;14:603.

28. Haus E, Reinberg A, Mauvieux B, Le Floc'h N, Sackett-Lundeen L, Touitou Y. Risk of obesity in male shift workers: A chronophysiological approach. Chronobiol Int 2016;33:1018-36. 
29. Peplonska B, Bukowska A, Sobala W. Association of Rotating Night Shift Work with BMI and Abdominal Obesity among Nurses and Midwives. PLoS One 2015;10:e0133761.

30. Moreno-Vecino B, Arija-Blázquez A, Pedrero-Chamizo R, GómezCabello A, Alegre LM, Pérez-López FR, González-Gross M, Casajús JA, Ara I; EXERNET Group. Sleep disturbance, obesity, physical fitness and quality of life in older women: EXERNET study group. Climacteric 2017;20:72-9.

31. Rahe C, Czira ME, Teismann H, Berger K. Associations between poor sleep quality and different measures of obesity. Sleep Med 2015; 16:1225-8.

32. Gökçe P. Gece vardiyasında çalışan hemşirelerde beslenme durumunun saptanması. Okan Üniversitesi, 2016.
33. Garcez AS, Canuto R, Paniz VMV, Olinto BA, Macagnan J, Henn RL, Pattussi MP, Olinto MTA. Association between work shift and the practice of physical activity among workers of a poultry processing plant in southern Brazil. Nutr Hosp 2015;31:2174-81.

34. Barbadoro P, Santarelli L, Croce N, Bracci M, Vincitorio D, Prospero E, Minelli A. Rotating shift-work as an independent risk factor for overweight Italian workers: a cross-sectional study. PLoS One 2013;8:e63289.

35. Smith P, Fritschi L, Reid A, Mustard C. The relationship between shift work and body mass index among Canadian nurses. Appl Nurs Res 2013;26:24-31. 